\title{
Study of Microbiological Quality of Biscuits from Street Side Bakery Shops at Dehradun City, India
}

\author{
Irtiqa Syed ${ }^{* 1}$, Rajendra Prasad ${ }^{2}$, Adeeba Naaz ${ }^{3}$ \\ *11Department of Biotechnology, Hindu College, Moradabad, INDIA \\ ${ }^{2}$ Department of Agriculture, School of Agriculture, Uttaranchal University, Dehradun, INDIA \\ ${ }^{3}$ Department of Biotechnology, Hindu College, Moradabad, INDIA
}

\begin{abstract}
In the present study, microbiological quality of biscuits from street side bakery shops at Dehardun city, India was conducted. A total 11 samples of bakery biscuits were collected randomly and analysed for their microbiologically quality by standard plate count method. Pure cultures of bacterial isolates were prepared by streaking on nutrient agar medium. Bacterial isolates were further studied for morphological characters, culture characters on nutrient agar medium and biochemical testes in laboratory. All samples studies were found contaminated by a variety of bacteria. The highest bacterial load was $2.2 \times 105 \mathrm{cfu} / \mathrm{g}$ and lowest was $0.1 \times 103$ cfu/g, respectively. Morphological observation, culture characters and results of biochemical tests of bacterial isolates were compared with standard results of known bacteria. The bacterial isolated were identified as Alcaligenes faecalis, Bacillus cereus, Micrococcus luteus, Pseudomonas aeruginosa, Streptococcus lactis and Staphylococcus aureus, respectively. Among these, two isolates i.e., A. faecalis and P. aeruginosa were gram negative and other isolates were gram positive bacteria which suggested the poor hygienic conditions inside the bakery during preparation and storage of biscuits. Gram positive bacteria might be contaminated during storage and by bad handling. These food spoiling bacteria might be responsible for food-borne infection and diseases. Therefore, care should be taken while purchasing such products and should be purchased from certified bakery shop.
\end{abstract}

Keywords : Bakery Biscuits, Contamination, Cleanliness, Microbiological quality, Standard Plate Count.

\section{INTRODUCTION}

In ancient era, people eat raw and poorly processed food. They did not know about the advantages of food processing. The time passed and man started thinking about the new items of food to change the taste and improve microbiological quality. Ingredients used in processed foods are the issue of research and experimentation because it has great importance in developing taste and assurance of quality.
Bakery products are the readymade food items made up of various ingredients, that are available anytime instantly and popular among the children throughout the world. These foods are also common part of snacks in urban cities. Main bakery products are bread, biscuits, cakes, pastries and other fermented and baked products. These days, consumers look for new bakery products, better appealing and taste. Bakery products are gaining popularity day by day. Youth prefer this type of food in their diet also. Somewhere bakery products are considered as an important part of balanced diet. Therefore, wide 
varieties of such products can be found in markets throughout the world including India [14].

Biscuits have higher value and production level than bread [16]. Studies showed that bakery products can provide a considerable energy intake [14]. Due to high nutritive value and affordable price, the bakery items have huge consumption. Biscuits are flat, crisp, baked good and are made up of with wide of cereals like gram flour, wheat flour etc. [22]. Biscuits become an important source of molecular carbohydrates, vegetable and minerals. Some microorganisms are useful for the production of bakery products as well as some other microorganisms can cause spoilage [11].

India is the second largest manufacturer of biscuits in the world after USA. In India, bread and biscuits are the major part of the bakery industry and covers around $80 \%$ of the total bakery products. Broadly bakery industries can be classified into two sectors: organized and unorganized. The organized industries of famous brands like Britannia, Sunfeast, Priya Gold, Anmol, Unibic Biscuits, etc. strictly follow Good laboratory practice (GLP) and quality of biscuits is assured and approved at several levels. Similarly, many established bakeries in local market also follow GLP and certified for good quality [16].However, bakery biscuits prepared by unorganized bakeries must be considered for scientific investigation. In present study, a total 11 samples of bakery biscuits were collected randomly from street side bakery shops at Dehardun city in India and their microbiologically quality were studied in the laboratory.

\section{METHODS AND MATERIAL}

All the chemicals, reagents and culture media used in present study were of HIMEDIA, Mumbai, INDIA. The common equipments used were: autoclave, laminar air flow, BOD incubator, serological water bath, Hot air oven, etc. All glassware used was borosilicate and sterilized.

\section{A. Place of Study:}

This was a laboratory based observational study, carried out in the Department of Microbiology TaqGene Training \& Research Institute (TGTRI), Dehradun, Uttarakhand a collaborative Institute of Uttaranchal University, Dehardun.

\section{B. Sample Collection:}

A total 11 samples (S-1, S-2, S-3, S-4, S-5, S-6, S-7, S8, S-9, S-10 and S-11) were collected randomly from street side bakery shops at Nanda-Ki-Chowki, Prem Nagar and Clock Tower in Dehradun city, India. The samples were taken to lab in sterilized bags and prepared immediately for microbiological tests.

\section{Sample Preparation:}

After surface sterilization, packets of biscuits were opened in laminar air flow and $10 \mathrm{~g}$ of sample was transferred in $90 \mathrm{ml}$ of sterilized distilled water for diluted sample preparation.

\section{Standard Plate Count:}

Standard plate counts of samples of biscuits were tested by spread plate method. Each sample was diluted by serial dilution method. One $\mathrm{ml}$ of sample was added in subsequent tube containing $9 \mathrm{ml}$ of distilled water. From each dilution of tube $0.1 \mathrm{ml}$ of inoculums was transferred on surface of nutrient agar medium in Petri plates. All Plates were incubated at $37 \pm 1^{\circ} \mathrm{C}$ for 18 hours in an inverted position in BOD incubator. The bacterial growth was observed in each Petri plate and isolated colonies were counted as colony forming unit (cfu).

\section{E. Preparation of Pure Culture:}

The isolated colonies showed similar culture characters in the Petri plates were observed and then purify on freshly prepared nutrient agar medium by 
streak plate method. Plates were incubated at $37 \pm 1^{\circ} \mathrm{C}$ for 18 hours in inverted position. The isolated colonies were transferred from streak plate to agar slants with the help of inoculating wire loop. The agar slants was incubated at $37 \pm 1^{\circ} \mathrm{C}$ for 18 hours and well grown cultures in slants were preserved at $4^{\circ} \mathrm{C}$ in a refrigerator for further use.

\section{1) MICROSCOPY}

Morphological characters of isolated colonies of bacteria were observed by standard method of Gram staining.

Motility of pure culture of bacterial isolates was observed on cavity slides by standards procedure of hanging drop method.

\section{2) CULTURE TEST}

Culture characters of pure culture of each bacterial isolate were observed carefully on nutrient agar medium.

\section{3) BIOCHEMICAL TEST}

The IMViC test is a group of individual tests used in microbiology lab testing for identification of specific bacteria.

\section{INDOLE TEST}

Tryptone was added to distilled water to make a broth. Isolated colony was inculated in tryptone broth and was incubated for 24-48 hours. After incubation period, result is read after adding Kovac's Indole reagent. The positive result is indicated by the Crimson red layer at the top of the tube. A negative result is indicated by the lack of color change at the top of the test tube.

\section{MR TEST}

The isolated colonies were inoculated in Methyl Red broth test tubes with the help of inoculating wire loop and were incubated for $24-48$ hours at $37^{\circ} \mathrm{C}$. After incubation period, result is read after adding
Methyl Red reagent. The positive test is indicated by the formation of red color .The negative test is indicated by no color change.

\section{VP TEST}

For VP test, empty test tube was taken and $1 \mathrm{ml}$ of VP media was pipetted out into it. In $1 \mathrm{ml}$ of $\mathrm{VP}, 0.6 \mathrm{ml}$ of $\alpha$-naphthol was added and then $0.2 \mathrm{ml}$ of $\mathrm{KOH}$ solution was added into it. The positive test shows red brown color. The negative test shows no color change.

\section{$>$ CITRATE UTILIZATION TEST}

The test is performed on Simmons citrate agar. Bacterial colony was suspended in the medium by streaking. It was incubated for 24-48 hours. The negative citrate test is indicated by lack of growth and color change. The positive citrate test is indicated by growth and a blue color change.

\section{TSI (TRIPLE SUGAR IRON) TEST}

TSI was inoculated by first stabbing through the center of the medium to the bottom of the tube and streaking on the surface of the agar slant. The tube was incubated at $37 \pm 1^{\circ} \mathrm{C}$ for 18 hours. Phenol red indicator turns into yellow both in butt and slant. It is possible only when lactose is fermented. The negative test is indicated when lactose, sucrose, glucose is not fermented both in butt and slants and turns red. If $\mathrm{H}_{2} \mathrm{~S}$ is produced, the black color at the bottom is seen.

\section{$>$ CATALASE TEST}

A clean slide was taken and suspended a drop of VP culture media on it. A drop of $\mathrm{H}_{2} \mathrm{O}_{2}$ was added on it.

Observe the bubble formation. Positive result shows immediate bubble formation. Negative result shows no bubble formation. 


\section{RESULTS AND DISCUSSION}

In present study, 11 samples of bakery biscuits were collected from different areas of Dehradun, India for analysis of microbiological quality. All samples studies were found contaminated by a variety of bacteria. The highest bacterial load was $2.2 \times 10^{5} \mathrm{cfu} / \mathrm{g}$ and lowest was $0.1 \times 10^{3} \mathrm{cfu} / \mathrm{g}$, respectively. Sample S-2, S3, S-7, S-8 were found highly contaminated with maximum bacterial count and S-1, S-9, S-10 were lesser contaminated as compared to other samples. Minimum of bacterial count were seen in S-5, S-6, S4, S-11. S-8, S-10 was shown with maximum number of different colonies whereas S-5, S-11 was shown with minimum number of colonies as given in table1.

Table - 1 : Standard Plate Count of Biscuit samples

\begin{tabular}{|c|c|c|}
\hline S. No. & Sample & $\begin{array}{c}\text { Bacterial count (cfu/g of } \\
\text { biscuits) }\end{array}$ \\
\hline 1 & S-1 & $4.0 \times 10^{3}$ \\
\hline 2 & S-2 & $2.2 \times 10^{5}$ \\
\hline 3 & S-3 & $6.0 \times 10^{4}$ \\
\hline 4 & S-4 & $1.010^{3}$ \\
\hline 5 & S-5 & $0.2 \times 10^{3}$ \\
\hline 6 & S-6 & $0.1 \times 10^{3}$ \\
\hline 7 & S-7 & $1.6 \times 10^{4}$ \\
\hline 8 & S-8 & $1.0 \times 10^{4}$ \\
\hline 9 & S-9 & $7.0 \times 10^{3}$ \\
\hline 10 & S-10 & $9.0 \times 10^{3}$ \\
\hline 11 & S-11 & $4.2 \times 10^{2}$ \\
\hline
\end{tabular}

It appeared that higher value of standard plate count (SPC) of biscuit samples might be due to various factors like improper handling, storage, unhygienic condition.
From the 11 samples of sweet and salt varieties of biscuits total 19 isolates were observed unique and identified by microscopy, culture and biochemical tests.

\section{MICROSCOPY}

Among all the 11 samples of biscuits, bacterial colonies were categorized as non-motile and motile. Except I-2, I-6, I-7, I-11 and I-18 other isolates were none motile.

Isolate I-1, I-3, I-4, I-8, I-9, I-10, I-12, I-13, I-14, I-15, I-17 and I-19 were found cocci shaped and gram positive. Bacterial isolates I-6, I-7, I-11, I-2, I-18, I-5 and I-16 were found rods shaped. Among these, I-6, I-7 and I-11 were gram positive and I-2, I-18, I-5 and I-16 were gram negative, respectively. There were slight variations in their cell arrangement that is some were arranging in bunches some in chain and some were solitary.

\section{CULTURE CHARACTERS OF ISOLATES OF BACTERIAL COLONY}

Samples were shown with a number of variations in culture characters. Colony color varies from white, pale yellow, orange, off white, etc. Colonies of sample I-6, I-7, I-8, I-9, I-10, I-11, I-12 and I-13 were white whereas some were pale yellow (I-1, I-3, I-14, I-17 and I-19). There were slightly difference in the size of the colony, size varies from 0.1 to 0.8 and no pigmentation was seen in colonies except sample I-2 and I-18 with bluish-green pigmentation. Elevations of most of the colonies were convex. There were some colonies with rough margin as well as smooth margin. Optical densities of some colonies were opaque while others were transparent, translucent. Maximum numbers of colonies were rounded while others were irregular in shape. 


\section{BIOCHEMICAL TESTS}

Pure culture of isolated colonies of bacteria showed variations in their IMViC and other biochemical tests. Isolates I-1, I-3, I-8, I-9, I-10, I-12, I-13, I-14, I-17, I19 were MR positive while other are negative. Colonies of all isolates showed Indole negative. Colonies of isolates I-6, I-7 and I-11 were VP positive and others were negative. There were variation in citrate utilization and TSI test of bacterial isolates. Colonies of isolates I-2, I-4, I-15 and I-18 were shown as citrate positive and others were negative. In TSI test colonies of isolates I-1, I-3, I-6, I-7, I-8, I-9, I-10, I-11, I-12, I-13, I-14, I-17 and I-19 were utilized all the three sugars whereas others were utilized sugars either partially or no utilization of sugar. Among the acid producing colonies in TSI tubes colonies of isolates I-2 and I-18 showed production of $\mathrm{H}_{2} \mathrm{~S}$ gas. Colonies of isolates I-1, I-2, I-3, I-5, I-14, I-16, I-17, I18 and I-19 were showed catalase positive while others showed catalase negative.

On the basis of microscopy, culture characters and biochemical tests bacterial isolates were identified as Alcaligenes faecalis, Bacillus cereus, Micrococcus luteus, Pseudomonas aeruginosa, Streptococcus lactis and Staphylococcus aureus.

Sample S-3, S-4 and S-6 were contaminated by B. cereus which is a highly infectious bacterium cause food-borne illness like diarrhoea, vomiting, etc. It survives in flour in form of spores. It multiplies quickly and produces toxins [19]. P. aeruginosa is a gram negative bacterium, rod shaped that can found commonly in the environment, like in soil and in water and in humans it can cause infections in the blood. In humans, it causes urinary tract infections, dermatitis and a variety of systemic infection [20].Samples contaminated with Staphylococcus spp. that was susceptible for food poisoning [21]. Species of many Bacillus sp. have been reported to be the major cause of rope spoilage in breads[11].B. cereus and $\mathrm{S}$. aureus have been reported to be the major source of contamination of some bakery products during improper handling, unhygienic condition.[12]

Table - 2 : Identification of Bacterial Isolates

\begin{tabular}{|l|l|l|l|}
\hline $\begin{array}{l}\text { S. } \\
\text { No }\end{array}$ & Isolates & Bacteria & $\begin{array}{l}\text { Positive } \\
\text { sample(s) }\end{array}$ \\
\hline 1 & I-6, I-7, I-11 & $\begin{array}{l}\text { Bacillus } \\
\text { cereus }\end{array}$ & S-3, S-4, S-6 \\
\hline 2 & I-4, I-15 & $\begin{array}{l}\text { Micrococcus } \\
\text { luteus }\end{array}$ & S-2, S-9 \\
\hline 3 & I-2, I-18 & $\begin{array}{l}\text { Pseudomonas } \\
\text { aeruginosa }\end{array}$ & S-1, S-11 \\
\hline 4 & $\begin{array}{l}\text { I-8, I-9, I-10, } \\
\text { I-12, I-13 }\end{array}$ & $\begin{array}{l}\text { Streptococcus } \\
\text { lactis }\end{array}$ & S-4, S-5, S-7 \\
\hline 5 & I-5, I-16 & $\begin{array}{l}\text { Alcaligenes } \\
\text { faecalis }\end{array}$ & S-3, S-10 \\
\hline 6 & $\begin{array}{l}\text { I-1, I-3, I-14, } \\
\text { I-17, I-19 }\end{array}$ & $\begin{array}{l}\text { Staphylococc } \\
\text { us aureus }\end{array}$ & $\begin{array}{l}\text { S-1, S-2, S-9, } \\
\text { S-11 }\end{array}$ \\
\hline
\end{tabular}

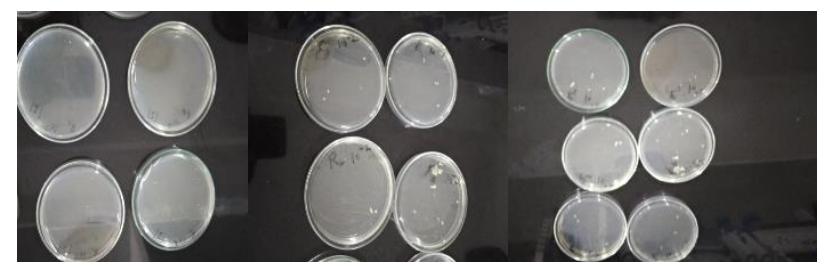

Fig-1: Standard Plate Count of samples

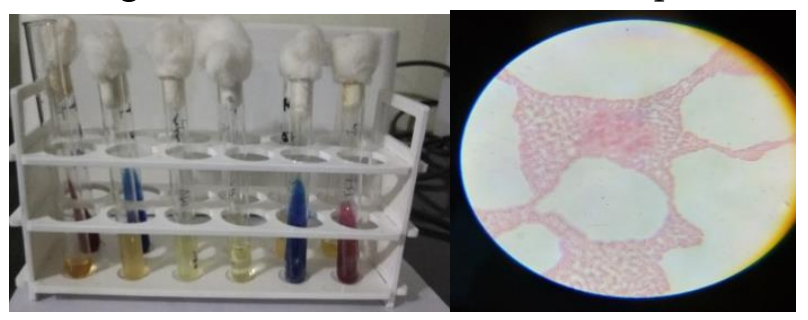

Biochemical (IMVIC) test (left) and Gram Staining (right) of Micrococcus luteus 


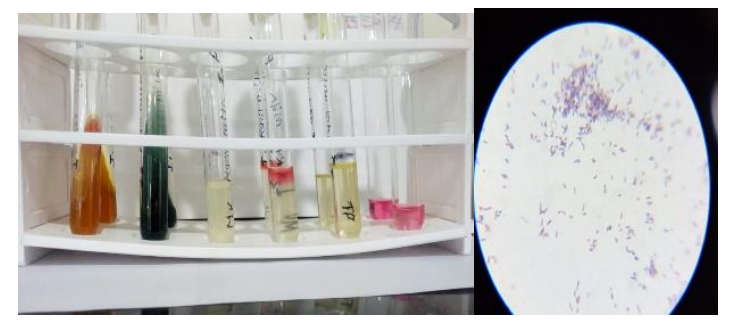

Biochemical (IMVIC) test (left) and Gram Staining (right) of Bacillus cereus

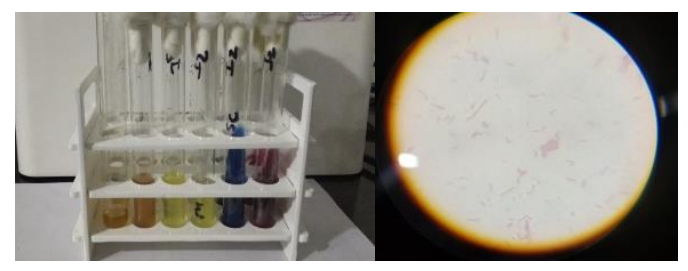

Biochemical (IMVIC) test (left) and Gram Staining (right) of Pseudomonas aeruginosa

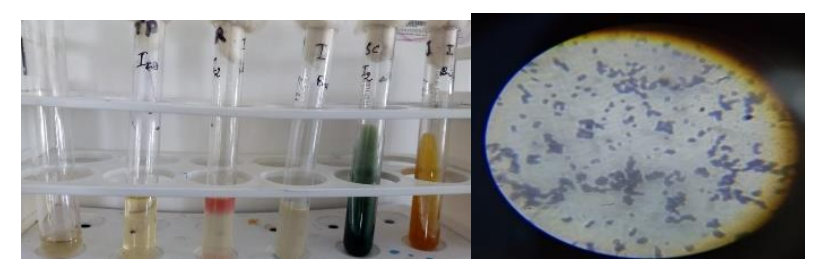

Biochemical (IMVIC) test (left) and Gram Staining (right) of Streptococcus lactis

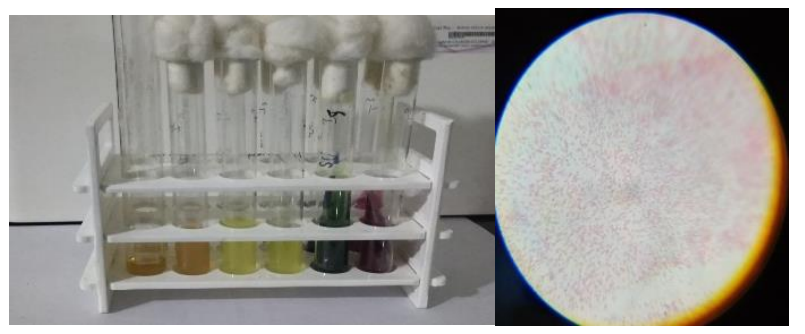

Biochemical (IMVIC) test (left) and Gram Staining (right) of Alcaligenes Faecalis

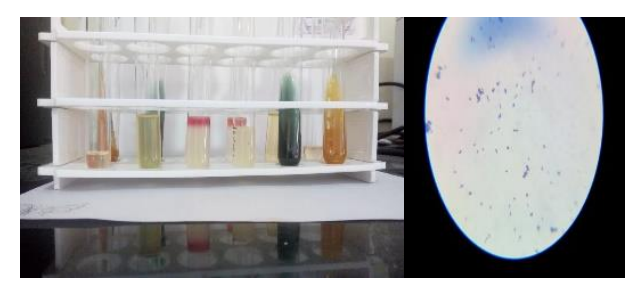

Biochemical (IMVIC) test (left) and Gram Staining (right) of Staphylococcus aureus

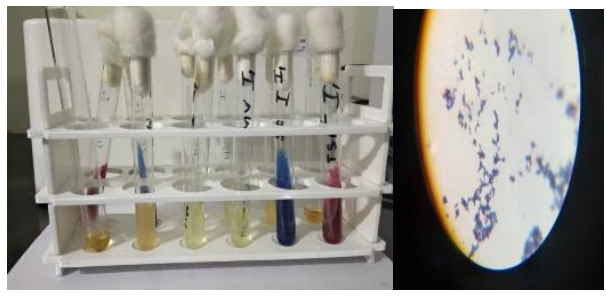

Biochemical (IMVIC) test (left) and Gram Staining (right) of Staphylococcus sp.

\section{Fig-2: Biochemical Identification \& Microscopy of Bacterial Isolates}

\section{CONCLUSION}

Freshly baked products are usually sterilized during preparation and do not contain feasible contamination by microorganisms. But during transportation and storage, baked products many times exposed in open environment and can be contaminated easily. Contamination also occurs due to unhygienic handling. Moreover, spore forming bacteria such as Bacillus subtilis and many fungi remained alive in bakery products if not processed properly [17]. Small quantities bacteria and fungi can cause serious food borne illness. Bacteria like Escherichia coli, P. aeruginosa, Salmonella typhi and many others have been considered an important pathogen which contaminate through untreated water used in bakery shops. These remained present in biscuits if baked improperly. They may cause serious illness in consumers. Besides, hygroscopic nature of bakery biscuits favors microbial contamination through aerosol in air [15]. The moisture content in the biscuits is about $3-5 \%$ which is not suitable for growth of microorganisms, however, bacterial and fungal spores can be survived up to certain time period. These microorganisms might be grown in favorable condition. Chance of contamination remained higher in open environment and during bad handling. 
From the present study, it is elucidated that many samples collected from street side bakery shops were severely contaminated. Microbial load differed widely in biscuit samples depending upon the location from where these were collected. Results suggested that extended efforts should be taken to maintain the hygienic conditions not only during baking but also during transportation and storage of bakery products in the shops. The hygienic steps should also be maintained by consumers during purchasing or consuming them. Moreover, the proper training for the food handler is anticipated as it affects the quality of product and plays an important role in the community health.

\section{REFERENCES}

[1]. I.C.Oladipo, S.B Ogunsona, O.S. Ojekanmi and A.O. Adegoroye (2019).Microbial And Nutritional Evaluation of Biscuits Produced from Wheat and Quality Protein Maize Flour. World journal of pharmaceutical life sciences, (January 2019), 5(1), 05-11 ISSN 2454-2229.

[2]. Mamat, H. and Hill, S. E. (2018) Structural and functional properties of major ingredients of biscuit. International Food research journal (April 2018), 2(2):462-471.

[3]. Z. E. Martins, O. Pinho, I. M. P. L. V.O Ferreira (2017) Food industry by-products used as functional ingredients of bakery products. Trends in Food science and technologytechnology, (september 2017), 67:106-128.

[4]. Noah Abimbola A (2017). Production, microbial and sensory qualities of biscuits produced from wheat-coconut-almond flour blend. International Journal of Food Science and Nutrition, 2(6):135-138.

[5]. Vishal Kumar Deshwal and Lovely Sharma. (2017). Assessment of Baked products at
Dehradun. International Journal of Research Granthaalayah, 5(10):46-50.

[6]. Khanom Afsana, Shammi Tahmina and Kabir Shahidul (2016). Determination of Microbiological of Packed and Unpacked Bread. Stanford Journal of Microbiology, 6(1): 24-29.

[7]. Alekhya Sabbithi, R. Naveen Kumar, L. Kashinath, V.Bhaskar, and V.Sudershaan Rao (2014). Microbiological Quality of Salads Served along with Street Foods of Hyderabad, India. International Journal of Microbiology, Article ID 932191:6 pages.

[8]. Ahmed Saghir and Ahmed Mushir (2014).A Review on Biscuit, a Largest Consumed Processed Product in India, Its Fortification and Nutritional Improvement. International Journal of Science Inventions Today.3 (2):169-186.

[9]. Udeme Joshua Josiah Ijah,Helen Shnada Auta,Mercy Oluwayemisi Aduloj and Sesan Abiodun Aransiola (2014).Microbiological, Nutritional and Sensory Quality of Bread Produced from Wheat and Potato Flour Blends, Nigeria. International Journal of Food Science, Article ID671701:6 Pages.

[10]. Helen obioma agu and ndidiamaka azuka okoli (2014) Physico-chemical, sensory and microbiological assessments of wheat based biscuit improved with beniseed and unripe plantain. Food science and nutrition, Sep; 2(5):464-469.

[11]. Saranraj, P and Geetha, M. (2012). Microbial Spoilage of Bakery Products and Its Control by Preservatives. International Journal of Pharmaceuticals \& Biological Archives, 3(1):3848.

[12]. Sarah D. Bennette, Kelly A. Walsh, L. Hannah Gould, Foodborne Disease Outbreaks caused by Bacillus cereus, Clostridium perfringens, and Staphylococcus aureus-United states, 19982008, Clinical Infectious Diseases, (august 2013),57(3) :425-433. 
[13]. Pundir, R.K. and Jain, P. (2011). Qualitative and quantitative analysis of micro flora of Indian Bakery Products. Journal of Agricultural Technology 7(3): 751-762.

[14]. Kumar,H, R. Palaha, D. Sharma, V. Sharma, D. Singh and A. Kaur. (2011). Microbiological quality analysis of the pastry sold in the Jalandhar city and public perception about the pastry. Internatinal Journal of Food Safety. 13: 361-366.

[15]. Saddozai Akhtar Ambreen and Khalil Samina (2009). Microbiological Status of Bakery Products Available In Islamabad. Pakistan Journal of Agriculture, 22(1):2.

[16]. Chavan J. K., Kadam S. S \& Dr. Reddy Ramka N. (2009) Nutritional enrichment of bakery products by supplementation with nonwheat flours. Critical Reviews in Food science and nutrition (sep 2009), 33(3):189-226.

[17]. Pepe O., Blaiotta G., Moschetti G., Greco T., Villani F.(2003) Rope producing strains of bacillus species from wheat bread and strategy for their control by Lactic acid bacteria.American Society for Microbiology(April 2003), 69(4) :2321-2329.

[18]. https://business.mapsofindia.com/indiaindustry/biscuits.html

[19]. https://www.ncbi.nlm.nih.gov/books/NBK4591 $21 /$

[20]. https://www.cdc.gov/hai/organisms/pseudomon as.html

[21]. https://www.medicinenet.com/staph_infection/ article.htm\#staph_infection_facts

[22]. http://ecoursesonline.iasri.res.in/pluginfile.php/ 154225/mod_resource/content/1/Lesson_12.htm

\section{Cite this article as :}

Irtiqa Syed, Rajendra Prasad, Adeeba Naaz, "Study of Microbiological Quality of Biscuits from Street Side Bakery Shops at Dehradun City, India", International Journal of Scientific Research in Science and Technology (IJSRST), Online ISSN : 2395-602X, Print ISSN : 2395-6011, Volume 7 Issue 3, pp. 319-326, May-June 2020. Available at doi : https://doi.org/10.32628/IJSRST207348 Journal URL : http://ijsrst.com/IJSRST207348 